\title{
Pengaruh Penggunaan Slag Nikel Terhadap Indeks Kekuatan Sisa Campuran HRS-WC
}

\author{
Ferlin Manguma $^{\star 1}$, Alpius ${ }^{\star 2}$, Charles Kamba ${ }^{\star 3}$ \\ *1 Mahasiswa Program Studi Teknik Sipil, Universitas Kristen Indonesia Paulus, Makassar, Indonesia \\ ferlin manguma@gmail.com \\ ${ }^{* 2 * 3}$ Dosen Program Studi Teknik Sipil, Universitas Kristen Indonesia Paulus, Makassar, Indonesia \\ alpiusnini@gmail.com dan kamba.chales@gmail.com
}

\begin{abstract}
ABSTRAK
Penelitian ini dimaksudkan untuk mengetahui pengaruh penggunaan slag nikel terhadap indeks kekuatan sisa Campuran Lataston HRS-WC. Metodologi dalam penelitian ini adalah melakukan serangkaian pengujian agregat kasar, dan halus kemudian merancang komposisi campuran Lataston HRS-WC dan HRS-BASE serta pengujian perendaman Marshall untuk memperoleh Indeks Kekuatan Sisa (IKS) / Indeks Perendaman (IP) / Durabilitas. Hasil penelitian ini yang dilakukan di laboratorium Jalan dan Aspal Fakultas Teknik Jurusan Sipil Universitas Kristen Indonesia Paulus Makassar, melalui uji perendaman Marshall diperoleh camuran Lataston HRS-WC dengan variasi kadar slag nikel 0\%, 25\%, 50\%, 75\% dan $100 \%$ dengan durasi waktu perendaman 0,5 jam dan 24 jam. Hasil pengujian Marshall campuran Lataston HRS-WC mendapatkan Indeks Kekuatan Sisa (IKS) / Indeks Perendaman (IP) / Durabilitas diperoleh nilai 92,84\% untuk 0\% Kadar slag nikel, 93,42\% untuk 25\% kadar slag nikel, 94,19 untuk 50\% kadar slag nikel, 93,03 untuk 75\% kadar slag nikel dan $97,06 \%$ untuk $100 \%$ kadar sag nikel sehingga terjadi kenaikan daya tahan campuran terhadap nilai indeks kekuatan sisa seiring dengan bertambahnya kadar slag nikel yang disubstitusi.
\end{abstract}

Kata Kunci : lataston, slag nikel, marshall immersion

\begin{abstract}
This study was intended to determine the effect of using nickel slag on the residual strength index of the Lataston HRSWC mixture. The methodology in this research is to carry out a series of coarse and fine aggregate tests then design the composition of the Lataston HRS-WC and HRS-BASE mixture as well as Marshall immersion testing to obtain the Residual Strength Index (IKS) / Immersion Index (IP) / Durability. The results of this study, which was conducted in the Road and Asphalt laboratory of the Faculty of Engineering, Department of Civil, Paulus Makassar, Indonesian Christian University, through the Marshall immersion test, the Lataston HRS-WC mixture was obtained with variations in nickel slag levels of $0 \%, 25 \%, 50 \%, 75 \%$, and $100 \%$. The immersion time duration of 0.5 hours and 24 hours. Marshall test results for Lataston HRS-WC mixture obtained Residual Strength Index (IKS) / Immersion Index (IP) / Durability obtained values of $92.84 \%$ for $0 \%$ nickel slag content, $93.42 \%$ for $25 \%$ nickel slag content, 94.19 for $50 \%$ nickel slag content, 93.03 for $75 \%$ nickel slag content and $97.06 \%$ for $100 \%$ nickel sag content so that there was an increase in the resistance of the mixture to the residual strength index value in line with the increase in the substituted nickel slag content.
\end{abstract}

Keywords: lataston, nickel slag, marshall immersion

\section{PENDAHULUAN}

Salah satu jenis sisa/limbah dari proses industri yaitu slag nikel yang merupakan akibat proses peleburan bijih nikel setelah melalui proses pembakaran dan penyaringan. Proses peleburan bijih nikel ini menghasilkan limbah yang berupa Slag nikel dalam jumlah yang cukup besar. Terak/slag nikel tersebut perlu ditangani atau dimanfaatkan dengan benar karena dapat menimbulkan masalah lingkungan serta fenomena sosial di masyarakat. Selama ini terak/slag nikel hanya digunakan sebagai bahan timbunan yang kurang memiliki nilai ekonomis. Oleh karena itu, penggunaan bahan sisa berupa slag nikel sebagai bahan pengganti agregat halus pada campuran Hot Rolled Sheet - Wearing Course merupakan salah satu alternatif solusi pengadaan material agregat halus sebagai bentuk pemanfaatan limbah yang secara ekomomis mampu meminimalisir dampak negatif berupa pencemaran lingkungan dan fenomena sosial di masyarakat. Secara visual terak/slag nikel menyerupai agregat baik agregat halus maupun agregat kasar yang biasa digunakan dalam campuran beraspal. Campuran aspal yang digunakan dalam penelitian ini adalah Hot Rolled Sheet (HRS-WC). Hot Rolled Sheet (HRS) adalah jenis campuran beraspal yang digunakan sebagai bahan pelapis suatu lapisan permukaan pada perkerasan jalan raya untuk menerima dan 
meneruskan beban lalu lintas ke lapisan dibawahnya sehingga dapat mempertahankan kekuatan konstruksi sampai tingkat tertentu. Keistimewaan $\mathrm{Hot}$ Rolled Sheet (HRS) yaitu mempunyai keawetan tinggi tetapi stabilitasnya rendah. Oleh sebab itu bersifat non structural. Hot Rolled Sheet (HRS) sangat cocok dipakai di daerah tropis seperti Indonesia [1].

Tujuan dari penelitian ini ialah untuk mengetahui pengaruh terhadap indeks kekuatan sisa campuran Lataston HRS-WC yang menggunakan slag nikel melalui pengujian perendaman Marshall. Slag nikel yang digunakan diperoleh dari Morowali.

Beberapa penelitian sejenis yaitu slag nikel sebagai pengganti agregat kasar dapat dimanfaatkan sebagai bahan perkerasan jalan lapisan HRS-Base [2], semakin tinggi kadar slag nikel, semakin tinggi kadar aspal optimum [3], berat agregat no.3/8 memberikan hasil yang baik ditinjau dari karakteristik MQ [4], semakin tinggi kadar aspal, semakin tinggi nilai VMA [5], penambahan kadar slag nikel menurunkan nilai VFB [6] , campuran HRS-WC dengan kadar aspal $5,9 \%, 6,4 \%, 6,9 \%, 7,4 \%, 7,9 \%$ dapat digunakan sebagai bahan perkerasan jalan [7],

\section{METODE}

Benda uji dibuat dengan variasi kadar slag nikel $0 \%$, $25 \%, 50 \%$, $75 \%$, dan $100 \%$ dari total agregat campuran dengan durasi waktu perendaman yang sama yaitu 0,5 dan 24 jam serta penggunaan kadar aspal yang sama.

Pemeriksaan karakteristik agregat kasar dan halus HRS-WC [8], [9].

\section{Analisa Saringan}

Pemeriksaan analisa saringan agregat kasar dan agregat halus mengacu pada metode atau standar SNI 03-1968-1990. Dengan rumus sebagai berikut :

$$
\begin{aligned}
& X(\%)=100 \%-\text { Kumulatif(\%) } \\
& Y(\%)=\sum \frac{W 10(\mathrm{gram})}{W 11(\mathrm{gram})}
\end{aligned}
$$

\section{Pemeriksaan berat jenis dan penyerapan air}

Pemeriksaan berat jenis dan penyerapan air agregat kasar mengacu pada standar rujukan SNI 03-19691990.

Pemeriksaan berat jenis dan penyerapan air agregat halus mengacu pada standar rujukan SNI 03-19701990.

Berat jenis bulk (atas dasar kering oven)

Berat jenis bulk $=\frac{W 7}{W 8-W 9}$
Berat jenis bulk (atas dasar kering permukaan)

Berat jenis bulk $=\frac{W 8}{W 8-W 9}$

Berat jenis semu

Berat jenis semu $=\frac{W 7}{W 8-W 9}$

Penyerapan air $\quad=\frac{W 8-W 9}{W 9}$

\section{Pemeriksaan kadar lumpur}

Pemeriksaan kadar lumpur dan SE (Sand Equivalent) mengacu pada standar rujukan SNI 03-4428-1997. Dihitung menggunakan rumus sebagai berikut :

$$
\mathrm{SE} \text { (Sand Equivalent) } \quad=\frac{s p}{s l} \times 100 \%
$$

Kadar lumpur $\quad=100 \%$ - SE

\section{Pengujian keausan (Abrassion)}

Pengujian Keausan (Abration) ini mengacu pada standar rujukan SNI 03-2417-1991. Dihitung dengan rumus :

Keausan $=\frac{W 12-W 13}{W 12}$

\section{Pemeriksaan indeks kepipihan dan kelonjongan}

Pemeriksaan indeks kepipihan dan kelonjongan mengacu pada standar rujukan ASTM D - 4791. Dihitung dengan rumus :

Indeks Kepipihan (\%) $=\frac{W 12(\mathrm{gram})}{W 13(\mathrm{gram})} \times 100 \%$

Indeks Kelonjongan (\%) =

$\frac{W 12(\mathrm{gram})}{W 13(\mathrm{gram})} \times 100 \%$

\section{Pemeriksaan material lolos saringan No.200}

Pemeriksaan material lolos sarin gan No.200 mengacu pada standar rujukan SNI 03-4142-1996. Dihitung dengan rumus:

Berat kering benda uji awal :

$$
\mathrm{w} 3=\mathrm{w} 1-\mathrm{w} 2
$$

Berat kering benda uji sesudah pencucian :

$\mathrm{w} 5=\mathrm{w} 4-\mathrm{w} 2$

Bahan lolos saringan 200 :

$$
w 6=\frac{w 3-w 5}{w 3} \times 100 \%
$$

\section{Indeks kekuatan sisa}

Indeks kekuatan sisa dianalisis dari data-data hasil pengujian terhadap sifat-sifat mekanik benda uji (stabilitas dan flow) dibagi dalam dua kelompok. 
Kelompok pertama diuji Stabilitas Marshallnya dengan perendaman dalam air pada suhu $60^{\circ} \mathrm{C}$ selama waktu $T_{1}$ dan kelompok kedua diuji setelah perendaman pada suhu $60^{\circ} \mathrm{C}$ selama $\mathrm{T}_{2}$ (Hunter, 2005).

$\mathrm{IKS}=\frac{S_{2}}{S_{1}} \times 100 \%$

Dimana:

$\mathrm{S}_{1} \quad=$ nilai rata-rata stabilitas Marshall setelah perendaman selama $T_{1}$ menit $(\mathrm{kg})$.

$\mathrm{S}_{2} \quad=$ nilai rata-rata stabilitas Marshall setelah perendaman selama $T_{2}$ menit $(\mathrm{kg})$.

IKS = Indeks Kekuatan Sisa (\%)

\section{Pembuatan Benda Uji Untuk Lataston HRS-WC}

Setelah semua bahan yang diperlukan lulus uji, maka tahapan selanjutnya adalah jumlah benda uji dan penyiapan bahan campuran sesuai dengan komposisi campuran (mix design) yang diperoleh. Dalam hal ini data-data yang diperoleh mengenai data karakteristik agregat, aspal, dan berat jenis filler diperoleh dari peneltian sebelumnya.

\section{Kadar Aspal Campuran Lataston HRS-WC}

Tabel 1. Campuran HRS-WC (Kadar Aspal 6,9\%)

\begin{tabular}{|c|c|c|c|c|c|c|c|c|c|}
\hline \multicolumn{2}{|c|}{ Ukuran saringan } & \multicolumn{3}{|c|}{ Lolos Saringan } & \multicolumn{3}{|c|}{ Tertahan Saringan } & \multirow{2}{*}{\multicolumn{2}{|c|}{ Komposisi Campuran (\%) }} \\
\hline Inchi & $\mathrm{Mm}$ & \multicolumn{2}{|c|}{ Spesifikasi $(\%)$} & $\begin{array}{c}\text { Gradasi } \\
\text { Campuran (\%) }\end{array}$ & $\begin{array}{c}\text { Berat } \\
(\%)\end{array}$ & $\begin{array}{c}\text { Berat Dalam } \\
\text { Campuran } \\
(\%)\end{array}$ & $\begin{array}{c}\text { Berat Dalam } \\
\text { Campuranl (gr) }\end{array}$ & & \\
\hline $1 \frac{1 / 2 "}{}$ & 37,500 & & & & & & & \multirow{6}{*}{17,70} & \multirow{6}{*}{ Agregat Kasar } \\
\hline $1 "$ & 25,000 & & & & & & & & \\
\hline $3 / 4^{\prime \prime}$ & 19,000 & \multicolumn{2}{|c|}{100} & 100 & & & & & \\
\hline $1 / 2^{\prime \prime}$ & 12,500 & 90 & \begin{tabular}{l|l}
. & 100 \\
\end{tabular} & 95 & 5 & 3,85 & 46,20 & & \\
\hline $3 / 8^{\prime \prime}$ & 9,500 & 75 & \begin{tabular}{l|l}
$\cdot$ & 85
\end{tabular} & 80 & 15 & 13,85 & 166,20 & & \\
\hline No.4 & & & & & & & & & \\
\hline $\begin{array}{ll}\mathrm{N} 0.8 \\
\end{array}$ & 2,360 & \begin{tabular}{|c|}
50 \\
\end{tabular} & \begin{tabular}{l|l}
$\cdot$ & 72 \\
\end{tabular} & 61 & 19 & 17,85 & 214,20 & \multirow{6}{*}{68,55} & \multirow{6}{*}{$\begin{array}{l}\text { Agregat Halus } \\
\text { (Pasir Silika) }\end{array}$} \\
\hline No.16 & & & & & & & & & \\
\hline No.30 & \begin{tabular}{|l|}
0,600 \\
\end{tabular} & 35 & \begin{tabular}{l|l}
. & 60 \\
\end{tabular} & 48 & 13,5 & 12,35 & 148,20 & & \\
\hline No.50 & & & & & & & & & \\
\hline No.100 & & & - & & & & & & \\
\hline No.200 & 0,075 & 6 & \begin{tabular}{l|l}
. & 10 \\
\end{tabular} & 8 & 39,5 & 38,35 & 460,20 & & \\
\hline \multicolumn{4}{|c|}{ Pan (filler) } & & 8 & 6,85 & 82,20 & 6,85 & Filler \\
\hline \multirow{2}{*}{\multicolumn{4}{|c|}{$\frac{\text { Aspal }}{\text { Total }}$}} & 6,9 & & 6,9 & 82,80 & 6,9 & Aspal \\
\hline & & & & & 100 & 100 & 1200 & 100 & \\
\hline
\end{tabular}

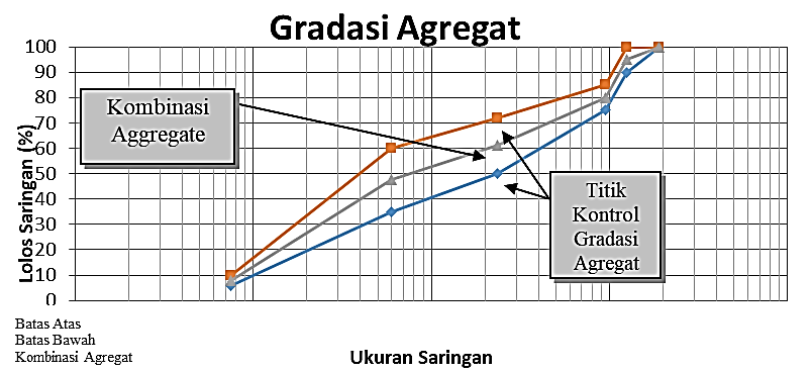

Gambar 1. Grafik gradasi campuran HRS-WC

\section{Proses penambahan Slag Nikel pada campuran Lataston HRS-WC}

Slag merupakan salah satu hasil limbah dari pengolahan nikel, proses peleburan bijih nikel tersebut menghasilkan limbah berupa slag/terak. Slag nikel yang digunakan pada penelitian ini adalah slag nikel dari morowali yang diambil langsung di pabrik yang ada di morowali. Proses pembuatan benda uji pada campuran Lataston HRS-WC adalah slag nikel ditimbang berdasarkan variasi kadar slag nikel yang digunakan adalah $0 \%, 25 \%, 50 \%, 75 \%$, dan $100 \%$ dari berat campuran. Kemudian aspal ditimbang dan dicampurkan dengan slag nikel, agregat, dan filler yang selanjutnya dilakukan pemadatan dengan alat pemadat.

Tabel 2. Rancangan benda uji campuran HRS-WC

\begin{tabular}{|c|c|c|c|}
\hline \multicolumn{4}{|c|}{ Campuran Lataston } \\
\hline \multicolumn{4}{|c|}{ HRS-WC } \\
\hline \multirow{2}{*}{$\begin{array}{c}\text { Kadar } \\
\text { Aspal } \\
(\%)\end{array}$} & \multirow{2}{*}{$\begin{array}{c}\text { Kadar Slag } \\
\text { Nikel (\%) }\end{array}$} & \multicolumn{2}{|c|}{ Durasi Perendaman (Jam) } \\
\hline & & 0,5 & 24 \\
\hline \multirow{5}{*}{6,9} & 0 & 3 & 3 \\
\hline & 25 & 3 & 3 \\
\hline & 50 & 3 & 3 \\
\hline & 75 & 3 & 3 \\
\hline & 100 & 3 & 3 \\
\hline \multirow{2}{*}{\multicolumn{2}{|c|}{ Total }} & 15 & 15 \\
\hline & & \multicolumn{2}{|c|}{30} \\
\hline
\end{tabular}

\section{Pengujian Marshall dan Marshall Immersion (Indeks Kekuatan Sisa)}

Dari pengujian indeks kekuatan sisa akan diperoleh nilai stabiltas. Stabilitas campuran beraspal diperoleh setelah perendaman benda uji yang memiliki kadar slag nikel yang berbeda-beda. Untuk mendapatkan nilai stabilitas pada marshall immersion maka benda uji direndam dengan suh air $60^{\circ} \mathrm{C}$ dan waktu perendaman 24 jam, sedangkan untuk nilai stabilitas marshall konventional benda uji direndam dengan suh air $60^{\circ} \mathrm{C}$ dan lama waktu perendaman 30 menit.

Indeks kekuatan sisa yang memenuhi spesifikasi dan yang terbaik adalah yang memiliki nilai terbesar.

\section{HASIL DAN PEMBAHASAN}

\section{Hasil Pengujian Keausan Dengan Alat Abrasi Los Angeles}

Hasil pengujian keausan agregat dengan menggunakan Alat Abrasi Los Angeles diperoleh nilai ketahan agregat kasar terhadap keausan dari Fraksi A adalah 5,76\%, Fraksi B adalah 6,92\%, Fraksi C 
adalah 9,28\% dan Fraksi D adalah 7,20\%. Semuanya memenuhi Spefikasi Umum Bina Marga 2018 yaitu maksimum $40 \%$. Dari hasil pengujian keausan agregat, dapat diketahui bahwa agregat berupa batu gunung Tandiallonan tidak mudah aus sehingga baik digunakan sebagai bahan lapisan permukaan.

Hasil pengujian berat jenis bulk dan penyerapan air agregat kasar

Hasil pengujian berat jenis dan penyerapan agregat kasar yang menggunakan dua sampel diperoleh nilai rata-rata untuk Berat Jenis Bulk adalah 2,66\% , berat jenis SSD adalah $2,69 \%$, berat jenis semu adalah $2,76 \%$ dan Penyerapan Air adalah 1,41\%. Semua hasil pengujian memenuhi Spefikasi Umum Bina Marga 2018 yaitu untuk Berat Jenis Bulk adalah minimal $2.5 \%$, Berat Jenis SSD adalah minimal 2,5 $\%$, Berat Jenis Semu adalah minimal $2,5 \%$ dan Penyerapan Air maksimal 3\%.

Hasil pengujian berat jenis bulk dan penyerapan air agregat halus

Hasil pengujian Berat Jenis dan Penyerapan Agregat Halus yang menggunakan dua sampel diperoleh nilai rata-rata untuk Berat Jenis Bulk adalah 2,55\%, Berat Jenis SSD adalah 2,58\%, Berat Jenis Semu adalah $2,64 \%$ dan Penyerapan Air adalah 1,32\%. Semua hasil pengujian memenuhi Spefikasi Umum Bina Marga 2018 yaitu untuk Berat Jenis Bulk adalah minimal 2,5\%, Berat Jenis SSD adalah minimal 2,5 $\%$, Berat Jenis Semu adalah minimal 2,5\% dan Penyerapan Air maksimal 3\%.

\section{Hasil pengujian analisa saringan HRS-WC}

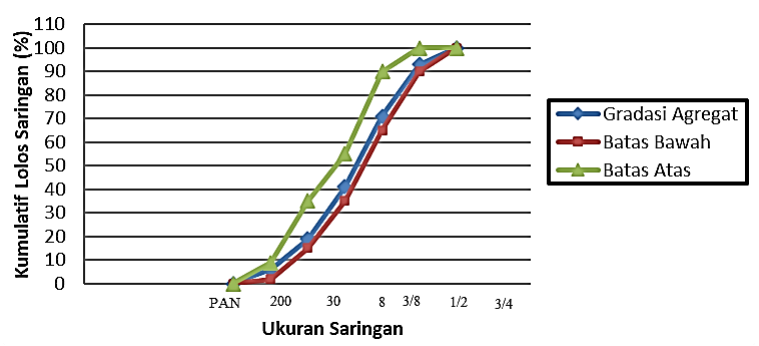

Gambar 2. Grafik analisa saringan

Hasil analisa saringan berupa gradasi agregat serta spesifikasinya dimana gradasi agregat berada ditengah antara batas atas dan batas bawah, ini menunjukkan bahwa agregat batu gunung Tandiallonan yang dipakai memenuhi standar spesifikasi untuk gradasi campuran yang dikeluarkan oleh Spefikasi Umum Bina Marga 2018.

\section{Hasil pengujian material lolos saringan No. 200}

Hasil pengujian material lolos saringan No. 200 adalah 4,40\%. Hasil Pengujian memenuhi Spesifikasi Umum Bina Marga 2018 yaitu maksimal
$8 \%$. Dapat di ketahui bahwa agregat berupa batu gunung Tandiallonan bersih dari lempung dan lanau.

\section{Hasil pengujian nilai setara pasir (Sand Equivalent)}

Hasil pengujian kadar lumpur dengan menggunakan 2 (dua) sampel diperoleh hasil rata-rata untuk nilai Sand Equivalent (SE) adalah 95,30\% dan kadar lumpur $4,70 \%$. Keduanya memenuhi Spefikasi Umum Bina Marga 2018 yaitu minimal 60\% untuk Sand Equivalent dan maksimal 5\% untuk kadar lumpur.

\section{Hasil pengujian partikel pipih dan lonjong}

Hasil pengujian Partikel Pipih dan Lonjong agregat diperoleh indeks kepipihan yaitu $9,50 \%, 5,50 \%$, $7,70 \%$, dan $7,60 \%$. Dan indeks kelonjongan yaitu $8,50 \%, 5,70 \%, 7,10 \%$ dan $9,50 \%$. Nilai Partikel Pipih dan Lonjong tersebut telah memenuhi Spefikasi Umum Bina Marga 2018 yaitu maksimal 10\%. Sehingga dapat disimpulkan bahwa pecahan (proses pemecahan batu secara manual di Laboratorium) batu gunung Tandiallonan berbentuk kubus (bidang pecah lebih dari satu).

\section{Hasil pengujian kelekatan agregat terhadap aspal}

Pengujian kelekatan agregat terhadap aspal ini hanya bersifat visualisasi yang tidak melalui proses perhitungan. Nilai kelekatan ditentukan dari luas permukaan sampel yang terselimuti aspal (kurang dari $95 \%$ atau lebih dari $95 \%$ ). Dari pengamatan ini dapat diketahui bahwa aspal dapat melekat dengan baik pada agregat.

\section{Hasil pengujian berat jenis filler}

Hasil pengujian berat jenis filler yaitu 3,05 Spesifikasi Umum Bina Marga 2018 tidak mencantumkan nilai batasan untuk berat jenis filler. Filler yang digunakan adalah semen dengan berat jenis 3,05 .

\section{Data Analisis Campuran Beraspal}

\section{Analisis stabilitas}

Tabel 3. Nilai stabilitas dari penggunaan variasi kadar slag nikel

\begin{tabular}{ccc}
\hline \multirow{2}{*}{$\begin{array}{c}\text { Kadar } \\
\text { Slag } \\
\text { Nikel } \\
(\%)\end{array}$} & $\begin{array}{c}\text { Waktu Perendaman } \\
\text { (Jam) }\end{array}$ & Min 600 \\
\cline { 2 - 3 } & & Stabilitas \\
\cline { 2 - 3 } 0 & 0,5 & 1383,69 \\
\cline { 2 - 3 } & 24 & 1284,58 \\
\hline \multirow{2}{*}{25} & Rata-rata & 1334,14 \\
\cline { 2 - 3 } & 0,5 & 1215,97 \\
\hline
\end{tabular}




\begin{tabular}{ccc}
\hline & Rata-rata & 1175,95 \\
\hline \multirow{3}{*}{50} & 0,5 & 983,45 \\
\cline { 2 - 3 } & 24 & 926,27 \\
\hline \multirow{2}{*}{75} & Rata-rata & 954,86 \\
\cline { 2 - 3 } & 0,5 & 865,28 \\
\cline { 2 - 3 } & 24 & 830,98 \\
\cline { 2 - 3 } 100 & Rata-rata & 848,13 \\
\cline { 2 - 3 } & 0,5 & 777,61 \\
\cline { 2 - 3 } & 24 & 764,74 \\
\hline
\end{tabular}

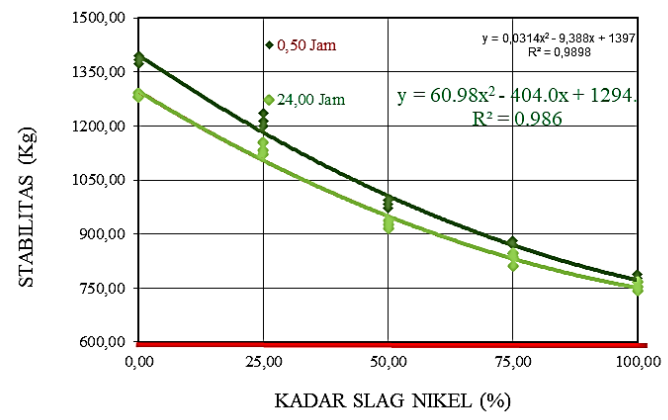

Gambar 3. Hubungan stabilitas terhadap variasi kadar slag nikel

Dengan menggunakan variasi kadar slag nikel yaitu 0\%, 25\%, 50\%, 75\%, dan $100 \%$ dengan durasi waktu perendaman 0,5 jam dan 24 jam untuk Lataston HRS-WC maka diperoleh nilai stabilitas pada variasi kadar slag nikel $0 \%$ antara 1284-1383,69, pada variasi slag nikel $25 \%$ antara $1135,92-1215,97$, pada variasi slag nikel $50 \%$ antara 926,27-983,45, pada variasi kadar slag nikel $75 \%$ antara $830,98-865,28$, pada variasi kadar slag nikel $100 \%$ antara $754,74-$ 777,61 .

Semakin besar kadar slag nikel yang disubstitusikan maka nilai stabilitas akan semakin kecil. Hal ini disebabkan karena tekstur permukaan slag nikel yang halus dan butir yang tidak beraturan (irreguler) sehingga mengakibatkan kurangnya ikatan antara butiran agregat dengan aspal dan sulit untuk mempertahankan agar film aspal itu tetap melekat.

\section{Analisis terhadap VIM}

Tabel 4. Nilai VIM terhadap variasi kadar slag nikel

\begin{tabular}{ccc}
\hline \multirow{2}{*}{$\begin{array}{c}\text { Kadar Slag } \\
\text { Nikel (\%) }\end{array}$} & $\begin{array}{c}\text { Waktu } \\
\text { Perendaman } \\
\text { (Jam) }\end{array}$ & VIM \\
\hline \multirow{2}{*}{0} & 0 & $4-6 \mathrm{~mm}$ \\
\cline { 2 - 3 } & 24 & 5,25 \\
\hline
\end{tabular}

\begin{tabular}{|c|c|c|}
\hline & Rata-Rata & 5,25 \\
\hline \multirow{3}{*}{25} & 0 & 5,05 \\
\hline & 24 & 5,03 \\
\hline & Rata-Rata & 5,04 \\
\hline \multirow{3}{*}{50} & 0 & 4,87 \\
\hline & 24 & 4,88 \\
\hline & Rata-Rata & 4,87 \\
\hline \multirow{3}{*}{75} & 0 & 4,66 \\
\hline & 24 & 4,62 \\
\hline & Rata-Rata & 4,64 \\
\hline \multirow{3}{*}{100} & 0 & 4,40 \\
\hline & 24 & 4,41 \\
\hline & Rata-Rata & 4,41 \\
\hline
\end{tabular}

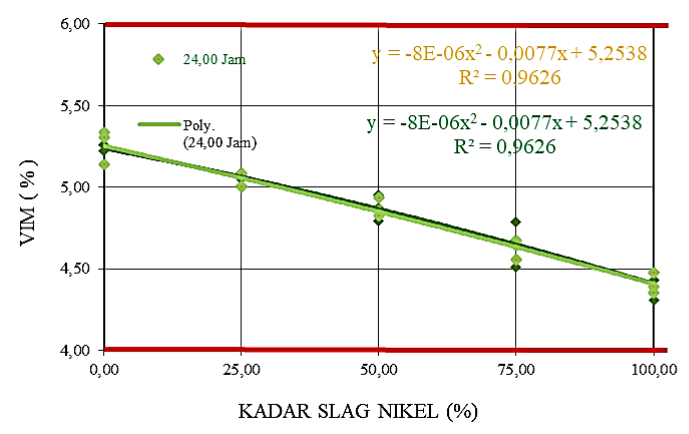

Gambar 4. Hubungan VIM terhadap variasi kadar slag nikel

Dengan menambahkan Slag nikel 0\% - 100\% pada Campuran Lataston HRS-WC maka diperoleh nilai VIM (Rongga dalam campuran yang tidak terisi aspal) antara $5.25 \%$ - $4.41 \%$ semuannya memenuhi Spesifikasi Umum Direkorat Jenderal Bina Marga 2018.

Semakin tinggi kadar slag nikel yang digunakan maka nilai VIM semakin kecil begitu pula sebaliknya, apabila kadar slag nikel yang digunakan semakin sedikit maka nilai VIM akan semakin besar. Hal ini dipengaruhi oleh susunan partikel dalam campuran yang tidak seragam sehingga rongga dalam campuran semakin kecil. Dengan rongga udara yang terlalu kecil dapat menimbulkan bleeding.

\section{Analisa VMA}

Tabel 5. Nilai VMA terhadap variasi kadar slag nikel

\begin{tabular}{ccc}
\hline $\begin{array}{c}\text { Kadar } \\
\text { Slag Nikel } \\
(\%)\end{array}$ & $\begin{array}{c}\text { Waktu Perendaman } \\
(\text { Jam })\end{array}$ & VMA \\
\cline { 2 - 3 } & 0 & Min 17\% \\
\cline { 2 - 3 } 0 & 24 & 19,92 \\
\hline 25 & Rata-Rata & 19,94 \\
\hline & 0 & 19,93 \\
\hline
\end{tabular}




\begin{tabular}{ccc}
\hline & 24 & 19,74 \\
\cline { 2 - 3 } & Rata-Rata & 19,75 \\
\hline \multirow{3}{*}{50} & 0 & 19,61 \\
\cline { 2 - 3 } & 24 & 19,61 \\
\cline { 2 - 3 } 75 & Rata-Rata & 19,61 \\
\cline { 2 - 3 } & 0 & 19,42 \\
\hline \multirow{2}{*}{100} & 24 & 19,40 \\
\cline { 2 - 3 } & Rata-Rata & 19,41 \\
\cline { 2 - 3 } & 0 & 19,21 \\
\cline { 2 - 3 } & 24 & 19,21 \\
\hline
\end{tabular}

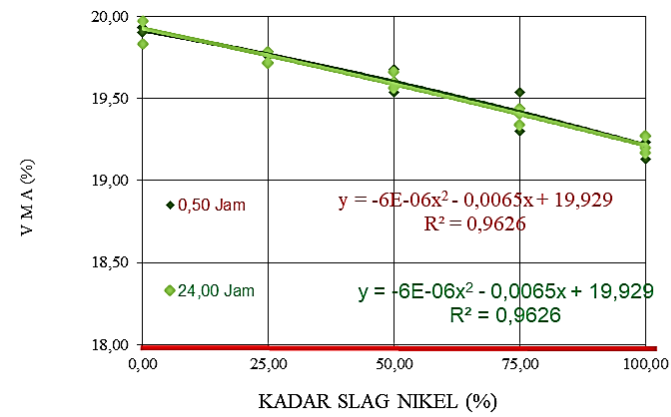

Gambar 5. Hubungan VMA dan kadar slag nikel

Dengan menggunakan Variasi kadar slag nikel 0\% $100 \%$ diperoleh nilai VMA (Rongga dalam agregat yang terisi aspal) antara $19.75 \%-19.21 \%$, dimana nilai VMA ini memenuhi Spesifikasi Umum Direktorat Jenderal Bina Marga 2018 yaitu minimal $17 \%$.

Semakin besar kadar slag nikel yang digunakan, maka rongga dalam agregat yang terisi aspal semakin berkurang. Hal ini dipengaruhi oleh gradasi agregat dalam campuran yang tidak seragam sehingga selimut aspal berkurang.

\section{Analisis VFB}

Tabel 6. Nilai VFB terhadap variasi kadar slag nikel

\begin{tabular}{ccc}
\hline \multirow{2}{*}{$\begin{array}{c}\text { Kadar Slag } \\
\text { Nikel (\%) }\end{array}$} & $\begin{array}{c}\text { Waktu } \\
\text { Perendaman (Jam) }\end{array}$ & VFB \\
\cline { 2 - 3 } 0 & 0 & Min 68\% \\
\cline { 2 - 3 } & 24 & 73,67 \\
\cline { 2 - 3 } & Rata-Rata & 73,61 \\
\hline \multirow{2}{*}{25} & 0 & 73,64 \\
\cline { 2 - 3 } & 24 & 74,45 \\
\hline \multirow{3}{*}{50} & Rata-Rata & 74,51 \\
\cline { 2 - 3 } & 0 & 75,14 \\
\cline { 2 - 3 } & 24 & 75,14 \\
\hline
\end{tabular}

\begin{tabular}{lcc}
\hline \multirow{3}{*}{75} & 0 & 76,03 \\
\cline { 2 - 3 } & 24 & 76,16 \\
\cline { 2 - 3 } & Rata-Rata & 76,10 \\
\hline \multirow{2}{*}{100} & 0 & 77,08 \\
\cline { 2 - 3 } & 24 & 77,06 \\
\cline { 2 - 3 } & Rata-Rata & 77,07 \\
\hline
\end{tabular}

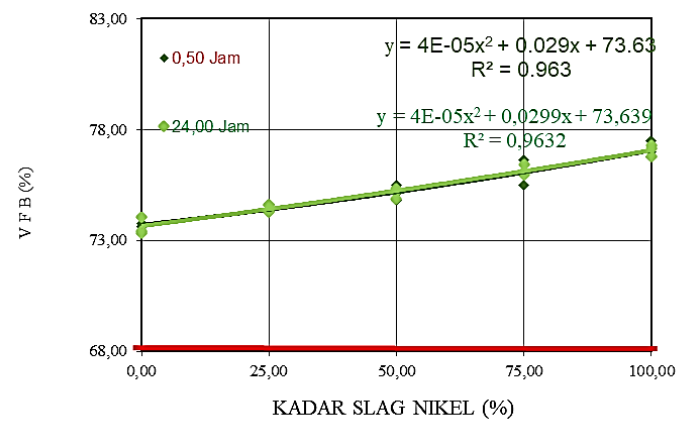

Gambar 6. Hubungan VFB dan kadar slag nikel

Dengan menggunakan kadar slag nikel 0\% - 100\% diperoleh nilai VFB antara $73.64 \%-77.07 \%$. Nilai VFB memenuhi Spesifikasi Umum Direktorat Jenderal Bina Marga 2018 yaitu minimal $65 \%$.

Semakin besar kadar slag nikel sebagai pengganti/substitusi agregat halus maka nilai VFB semakin besar. Hal ini berarti bahwa rongga udara berisi aspal sehingga kepadatan campuran terhadap air dan udara tinggi. Hal ini dipengaruhi oleh bentuk butir dari slag nikel.

\section{Analisis terhadap $M Q$}

Tabel 7. MQ terhadap kadar slag nikel

\begin{tabular}{|c|c|c|}
\hline \multirow{2}{*}{$\begin{array}{l}\text { Kadar Slag } \\
\text { Nikel (\%) }\end{array}$} & \multirow{2}{*}{$\begin{array}{l}\text { Waktu Perendaman } \\
\text { (Jam) }\end{array}$} & \multirow{2}{*}{$\begin{array}{c}\text { Min } 250 \\
M Q\end{array}$} \\
\hline & & \\
\hline \multirow{3}{*}{0} & 0,5 & 659,59 \\
\hline & 24 & 573,57 \\
\hline & Rata-rata & 616,58 \\
\hline \multirow{3}{*}{25} & 0,5 & 523,37 \\
\hline & 24 & 479,46 \\
\hline & Rata-rata & 501,42 \\
\hline \multirow{3}{*}{50} & 0,5 & 388,22 \\
\hline & 24 & 354,00 \\
\hline & Rata-rata & 371,11 \\
\hline \multirow{3}{*}{75} & 0,5 & 317,40 \\
\hline & 24 & 292,25 \\
\hline & Rata-rata & 304,83 \\
\hline \multirow{3}{*}{100} & 0,5 & 239,04 \\
\hline & 24 & 225,79 \\
\hline & Rata-rata & 232,42 \\
\hline
\end{tabular}




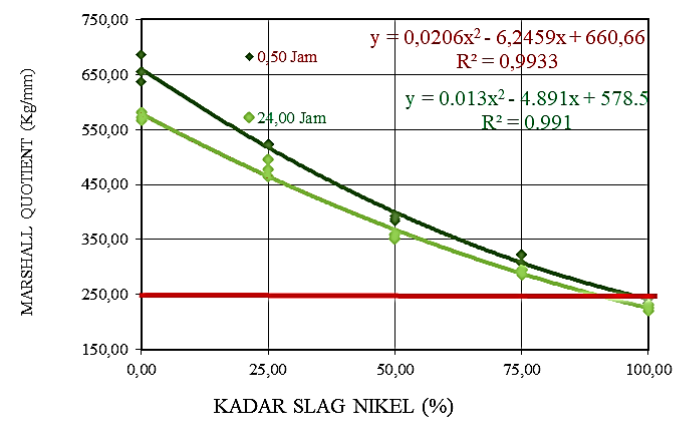

Gambar 7. Nilai $M Q$ terhadap variasi kadar slag nikel

MQ adalah hasil bagi antara Stabilitas dengan flow/kelenturan. Dengan menggunakan kadar slag nikel 0\% - 100\% diperoleh nilai MQ antara 616.58 $\mathrm{Kg} / \mathrm{mm}$ - $232.42 \mathrm{Kg} / \mathrm{mm}$. Nilai MQ memenuhi Spesifikasi Umum Direktorat Jenderal Bina Marga 2018 yaitu minimal $250 \mathrm{Kg} / \mathrm{mm}$. Namun pada kadar slag nikel $100 \%$ nilai MQ tidak memenuhi. Dapat dilihat pada Gambar 12 bahwa semakin besar kadar slag nikel sebagai pengganti/substitusi agregat halus, maka semakin kecil nilai $\mathrm{MQ}$.

\section{Kadar Slag Nikel Optimum}

Berdasarkan hasil pengujian Marshall dan analisis karakteristik Campuran Lataston HRS-WC dapat ditentukan kadar slag nikel praktis dalam campuran beton aspal yaitu kadar Substitusi slag nikel yang memenuhi semua kriteria atau karakteristik Campuran dan kadar slag nikel praktis tersebut adalah rentang Kadar Slag Nikel $25 \%-100 \%$. Untuk ke tahapan pengujian selanjutnya yaitu Indeks Perendaman (IP) / Indeks Kekuatan Sisa (IKS) / Durabilitas/Ketahanan Campuran Lataston HRS-WC akibat perendaman, maka sesuai fungsinya yaitu melindungi lapisan yang ada di bawahnya yaitu HRS WC dan lebih kedap air untuk itu ditentukan Campuran yang memiliki Stabilitas terkecil serta VIM terkecil yaitu kadar slag nikel $100 \%$

\begin{tabular}{|c|c|c|c|c|c|c|c|c|}
\hline \multirow{7}{*}{ 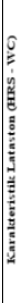 } & VIM (\%) & $4.0-6.0$ & & & & & & \multirow{5}{*}{$\begin{array}{l}\text { Ket: } \\
\text { Berwarna = Memenuhi Spesifikasi } \\
\text { Tidak Berwarna = Tidak Memenuhi } \\
\text { Spesifikasi }\end{array}$} \\
\hline & $\operatorname{VFB}(\%)$ & $\overline{M i n}$ & & & & & & \\
\hline & Stabilitas $(\mathrm{kg})$ & $\operatorname{Min} 600$ & & & & & & \\
\hline & $\mathrm{MQ}(\mathrm{Kg} / \mathrm{mm})$ & Min $^{\prime} 250$ & & & & & & \\
\hline & \multirow[t]{2}{*}{$\operatorname{VMA}(\%)$} & \begin{tabular}{|l|l|}
$\mathrm{M}$ in & 18 \\
\end{tabular} & & & & & & \\
\hline & & & 0,00 & 25,00 & 50,00 & 75,00 & 100,00 & \\
\hline & \multicolumn{7}{|c|}{ Kadar Slag Nikel (\%) } & \\
\hline
\end{tabular}

Gambar 8. Diagram kadar slag nikel optimum

\section{Indeks Kekuatan Sisa}

Setelah penentuan Kadar Slag Nikel optimum, maka langkah selanjutnya adalah membuat beda uji berdasarkan Kadar Slag Nikel optimum, $100 \%$ untuk
Campuran Lataston HRS-WC yang kemudian direndam selama \pm 24 jam pada suhu $\pm 60^{\circ} \mathrm{C}$.

Indeks Perendaman (IP)/ Indeks Kekuatan Sisa (IKS) / Durabilitas/Ketahanan Campuran Lataston HRSWC diperoleh dari perbandinganSabilitas Campuran setelah direndam pada durasi waktu 24 jam dengan Stabilitas campuran yang direndam selama 0,5 jam.

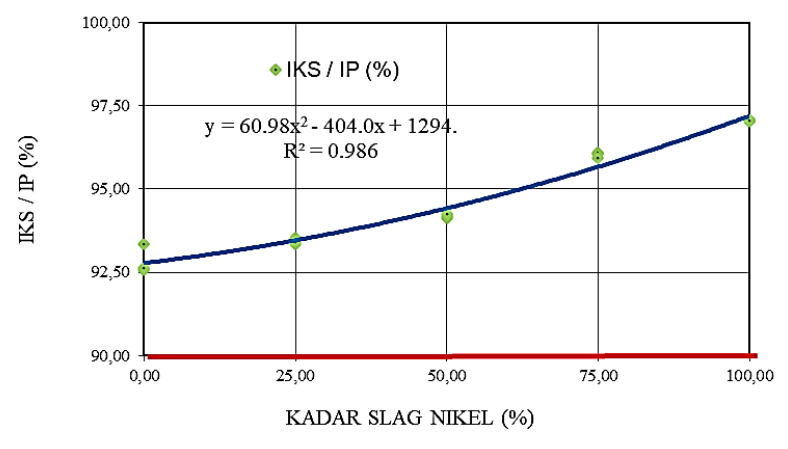

Gambar 9. Hubungan kadar slag nikel dan indeks kekuatan sisa

Dari hasil pengujian perendaman campuran Lataston HRS-WC yang menggunakan variasi substitusi slag nikel dengan durasi waktu $0.5-24$ jam, pada variasi substitusi slag nikel $0 \%$ diperoleh nilai indeks kekuatan sisa $92.84 \%$ pada variasi substitusi slag nikel $25 \%$ diperoleh nilai indeks kekuatan sisa 93.42 $\%$ pada variasi substitusi slag nikel $50 \%$, \% diperoleh nilai indeks kekuatan sisa $94.19 \%$ pada variasi substitusi slag nikel $75 \%$ diperoleh nilai indeks kekuatan sisa $96.03 \%$ dan untuk variasi substitusi slag nikel $100 \%$ diperoleh nilai indeks kekuatan sisa $97.06 \%$. Terjadi kenaikan daya tahan campuran lataston HRS-WC dari variasi substiusi slag nikel $0 \%$ - $100 \%$. Hal ini terjadi Karena pori yang terbentuk dalam campuran setelah pemadatan kecil karena bentuk butir dari slag nikel yang tidak beraturan (Irregular) sehingga semakin banyak kandungan salg nikel campuran semakin rapat dan campuran pun kedap air.

\section{Pembahasan}

\section{Karakteristik bahan}

Hasil pengujian karakteristik bahan berupa Agregat Kasar, Agregat Halus dari batu gunung Tandiallonan Kecamatan Makale Kabupaten Tana Toraja, Provinsi Sulawesi Selatan dan sebagai bahan substitusi agregat halus berupa slag nikel yang diperoleh dari morowali, filler yang menggunakan semen Portland serta aspal penetrasi 60/70 yang telah memenuhi standar yang ditetapkan Bina Marga 2018. 


\section{Karakteristik campuran lataston HRS-WC}

Kenaikan IKS/IP sebesar rata-rata $1.04 \%$ seiring dengan bertambahnya Proporsi Substitusi slag nikel dalam campuran Lataston HRS-WC

\section{KESIMPULAN}

Pengaruh terhadap indeks kekuatan sisa campuran Lataston HRS-WC yang menggunakan slag nikel menunjukan bahwa terjadi peningkatan daya tahan campuran seiring dengan bertambahnya skadar lag nikel yang disubstitusi. Hal ini dipengaruhi oleh bentuk slag nikel yang tidak beraturan sehingga semakin banyak kadar slag nikel maka campuran akan semakin rapat dan campuran pun semakin kedap air.

\section{DAFTAR PUSTAKA}

[1] G. Rusbintardjo, Aspal- Bahan Perkerasan Jalan, 1 ed. Semarang, Indonesia: UNISSULA Press, 2013.

[2] U. A. Demmalino, W. S. C. Lambe, Alpius, dan R. Rachman, "Pengujian Slag Nikel Sebagai Pengganti Agregat pada Campuran HRS-Base," Paulus Civ. Eng. J., vol. 1, no. 2, hlm. 44 - 49, 2019.

[3] Daud, R. Rachman, dan J. Tanijaya, "Study of HRS-WC Mixture Performance Using the Waste of Crude Palm Oil Ash as Filler," Bali, Indonesia, 2020, vol. 419, doi: 10.1088/1755$1315 / 419 / 1 / 012101$
[4] A. Kusuma dan R. Rachman, "Study Characteristics of Nickel Slag For Gradient Gap on Mixtured Hot Rolled Sheet Base," Int. J. Innov. Sci. Eng. Technol., vol. 5, no. 3, hlm. 8-13, 2018.

[5] C. Kamba dan R. Rachman, "Marshall Characteristics Test On Hot Rolled Sheet Base Combine Using Nickel Slag For Half Gap Graded," Int. J. Innov. Sci. Eng. Technol., vol. 5, no. 3, hlm. 14-19, 2018.

[6] R. Rachman, "The Effect of Immersion and Humidification toward Performance of Hot Rolled Asphalt Mixture," Int. J. Appl. Eng. Res., vol. 15, no. 5, hlm. 503-509, 2020.

[7] M. T. A. Meitari, S. Morai, C. Kamba, dan Alpius, "Pengujian Batu Apung Sebagai Filler pada Campuran HRS-Base," Paulus Civ. Eng. J., vol. 1, no. 1, hlm. 44 - 57, 2019.

[8] Direktur Jenderal Bina Marga, Manual Desain Perkerasan Jalan Revisi 2017. Jakarta, Indonesia: Kementrian Pekerjaan Umum dan Perumahan Rakyat, 2017.

[9] Direkorat Jenderal Bina Marga, Spesifikasi Umum Bina Marga 2018 untuk Pekerjaan Konstruksi Jalan dan Jembatan. Jakarta Indonesia: Kementerian Pekerjaan Umum dan Perumahan Rakyat, 2018. 